\title{
Issues of Education Surrounding Native American art at the Iroquois Indian Museum
}

\section{JILL HOFFMAN}

Issues surrounding Native American art include how to define Native art and its artists. Such issues are not merely the source of interesting philosophical debates. These matters have had to be handled within our judicial system resulting in laws that, for example, mandate the ways in which museums are to acknowledge and act upon requests for the return of certain objects held sacred by Native communities. For instance, the Indian Arts and Crafts Law attempts to protect Native-made arts and crafts from non-Natives who tried to cash in on a billion dollar industry. These legislative actions suggest that Native Americans endure a unique relationship with federal authorities directly because of their art. The economic tie between Indians and art involves a history of intervention by museums, anthropologists, philanthropists, and art educators. These same entities have helped to create our perceptions and definitions of Native art and the market within which such exists. While Native art has been created by Native Americans it has often been controlled by non-Natives.

Native and non-Native curators, gallery owners, critics, and others express varying opinions about how to define Native art. Some would say that Native American art is only that which is old. There exists a blur between the boundary of anthropology and fine art, some objects having endured an aesthetic shift. The popularity of collections of Native objects and the pastiche of "Native American" patterns and colors utilized in contemporary design reveal the romanticized popular notions with which we regard Indians.

Within such a market, Indians are perceived as significant oniy in that they are the fabricators for such collectibles--vaiued more is the object as souvenir of the "noble savage." Perhaps the popularity of photographs by Edward Sheriff Curtis, for example, suggests that the image of the Indian of the past reinforces our collective impression of what an "Indian" is. Such images and ideas help to keep our understanding of Native people located and frozen in the past. Enculturated stereotypes of Native people, reinforced by media and popular culture images, do not encourage us to confront the reality of contemporary Indian lives.

Debates which surround Native American art are not the only controversy within the Native art arena. Persons who are of Native American heritage who are also artists find themselves in the midst of various debates. Some would argue that the true Indian artist is one whose creative efforts 
reflects their tribes particular aesthetic forms. Others would argue that the "real" Indian artist is the one who produces work in the style associated with Dorothy Dunn, who, as an art educator, instructed Indian students in painting in Santa Fe in the 1930's. Still others would claim that the true Native art reflects the break with tradition usually associated with artists Fritz Scholder and T. C. Cannon during their tenure with the Institute of American Indian Arts. Still others believe that Indian artists are those easily identified with the Santa Fe Market or that their work should reflect "Indian themes." Individuals of Indian heritage who as artists work in contemporary forms of expression have variously experienced displacement as they are categorized according to their heritage. The effects of such debates about defining Native art and artists is revealed in the experience of native photographers. As Rick Hill told me, as recently as twenty years ago he could not get into exhibitions of Indian art because photography was not considered an "acceptable" category for Native American artists.

It is within this context of debates that I began my research into educational issues which impact the interpretation of Native American art. It soon became evident that museums have historically contributed a great deal to the ways in which Native American art and people are defined. Also, the emergence of Native museums makes the institution a common resource among Native and non-Native persons who try to make Native culture accessible. Because of the current debates surrounding Native American art, the history of relationships between museums and Native communities and the current challenges to museums by those who have been historically excluded, I wanted to know more about how non-Natives attempt to portray a culture outside of their own experience, and how Native persons regard the efforts of non-Natives as they seek to portray Native culture.

Through a committee member, Dr. Victor Dupuis, Mohawk, Professor Emeritus at The Pennsylvania State University, I became aware of the Iroquois Indian Museum in Howes Cave, New York. The museum, located near Albany, New York, in what was originally Mohawk territory, is an anthropology museum which collects and exhibits contemporary Iroquois art. The museum was established, and is staffed and managed by non-Iroquois persons with the exception of a single Iroquois staff member and several Iroquois board members.

"Iroquois" is a word, originally used by the French, which refers to the people of the Six Nations Confederacy, specifically the Mohawk, Oneida, Onondaga, Seneca, Cayuga and Tuscarora. Collectively, these people call themselves "Haudonosaunee," the people of the Longhouse. The Longhouse refers to not only a housing structure but to an organized

Marilyn Zurmuehlen's Working Papers In Art Education 1994-1995 
practice of beliefs and ceremonies. The Iroquois Indian Museum seeks to present the art, history and anthropology of all the nations of the Iroquois.

Located in Schoharie county near Cobleskill, New York, the museum is situated in one of the most rural and low income areas of the state. Visitors to the museum are primarily from two groups: tourists and schoolchildren. The museum is located near Interstate 80 adjacent to a popular tourist site, Howes Cave. Many fourth grade and seventh local history, which many interpret to mean the history of the Iroquois.

The Iroquois Indian Museum exhibits contemporary iroquois art and also displays a variety of historical and archaeological objects. Educational activities show similar ties to other museums: a video installation, which presents Iroquois discussing their work; a children's museum which is utilized along with the main gallery for a variety of school programs including storytelling, programs about lacrosse, and experiences with artists materials; artist demonstrations; and lectures. The annual Iroquois Arts Festival allows the public to speak with and purchase art from some of the most well-known Iroquois artists and to enjoy Native music and the opportunity to see Iroquois dancers of which there are several internationally known groups A nature trail is the focus of the museum's programs on Iroquois cosmology and ethnobotany.

I began my study by conducting interviews with the staff of the iroquois indian Museum as well as two board members and four Iroquois individuals. For context, I visited other Iroquois-managed museums, all of which are in New York State. These include, the Seneca-Iroquois Museum in Salamanca, the Oneida Cultural Center in Oneida, and the Six Nations Museum in Onchiota. Unlike the Iroquois Indian Museum (hereafter referred to as IIM), these tribal/community museums managed by Iroquois persons exist as cultural and historical resources for people within the local Iroquois community. The Iroquois Indian museum exists to educate non-Iroquois about Iroquois culture.

Museums are currently challenged with a variety of problems which involve how to address the demands put forth by those cultures, communities, and individual artists who have been excluded from dialogues, exhibitions, and scholarly acknowledgment. My personal interest is in those issues which surround Native American art, culture and people. Of most interest to $m e$ is the realization that even as advanced as we may perceive ourselves to be late in the twentieth century, our American society still relates to Native communities in ways that seem archaic. I am both fascinated and troubled that legislation is still created which effects Native people directly 
because ot their art, culture, religion, and home lands. in many ways, nonNatives, myself included, have more to learn and understand about Native Americans. Museums are possibly one way in which such learning can occur.

My study on the IIM was begun in wanting to know more about how Native art and culture is presented and discussed within the context of a museum. In the interviews, I asked questions to which answers would be of interest to me, and hopefully other non-Native educators, in trying to interpret Native art. The interviews within which I participated were conducted from a generally informed study of the history and issues of Native American art, culture and museum relations. I also wanted the opportunity to speak with Native persons directly to find out their thoughts on how Native art, culture and people are presented within a museum.

Those who participated in this study include: Michael Butler park manager for the IIM: Dave Fadden, Mohawk, educator at the IIM: John Fadden, Mohawk, co-manager of the Six Nations Museum, a family operated museum in Onchiota New York; Dr. John Ferguson, chair of the IIM board and former professor of anthropology at SUNY Cobleskill; Paul Fleishman, board member at the Museum; Cr. Christina Johannsen Hanks, founder and former director of the Iroquois Indian Museum; Richard (Rick) W. Hill, Sr., Tuscarora, artist and museum professional, currently special assistant to the director of the National Museum of the American indian; Colette Lemmon, assistant director of public programs at the IIM; Catherine Raddatz, assistant director of business for the IIM; Stephanie Shultes, assistant director for anthropology at the IIM; and Mike Tarbell, Mohawk, former educator at the IIM. The questions that I asked reflect my interest in knowing more about how Native culture is portrayed at the IIM; how Iroquois persons perceive efforts of non-Native educators; and visitor expectations within the museum.

After conducting taped interviews with all of the participants, I then transcribed the conversations and provided each participant with a copy so that they could review their comments. With only one exception, Mike Butler, the interviews are reproduced in full text within the dissertation and a review of these conversations reveals a variety of concerns and issues which relate to educational efforts in presenting Native American art at the IIM. In speaking with the museum staff and the Iroquois persons who participated in my questions, several issues became evident. While my interest was upon the educational aspects of the museum, the insights gained through the interviews and observations of programming are points which I think are applicable to other museums which would exhibit Native American art. These have implications for how we teach about Native art and culture, and the knowledge that we impart about such entities. Generally, issues which 1 
became aware of have to do with communication between individuals, cultures, visitors and museum staff. I have described the issues raised by the participants according to eight categories.

1. The General Nature of Museums. The utilization of a museum to teach about Native art and culture is not an unusual practice even within Native communities. Many tribal museums re located within Indian communities and serve to teach about Native culture, history, and language. The IIM exists to teach non-Natives, primarily about Iroquois art and culture. What is important to note regarding this study and the IIM is the way in which the IIM emphasizes the present and not the past in the way that many mainstream museums present Native American culture. While historical and archaeological aspects are utilized, indeed necessary, to further understanding of specific aspects of Iroquois life, the IIM's emphasis upon the present, the contemporary people, helps visitors to begin to reformulate their understandings about Native persons. In the IIM, the Iroquois, and all Native Americans, are presented to the public as part of living, viable, contemporary cultures and not as specimens of the past.

2. The Museum as a Resource. The IIM is not merely an exhibition space for art and other objects. For Iroquois artists, and many of their families, the IIM is a major marketing tool for their creativity which in turn helps to provide income. The IIM is a link between other museums and collectors and the many Iroquois artists who have been largely ignored within the Native American art circle. Many persons think of only the Southwest and its market when considering Native art, but for the Iroquois artists who seek to present their creative efforts the IIM has provided, for some, an access to others who want to know more about their work. The museum aiso provides for interaction between the Iroquois artists and the buying public through the annual arts festival held at the museum. So, more than just providing an exhibition schedule, the IIM plays a role in the marketing of contemporary Iroquois art.

3. Problems Encountered by Iroquois (Native) Staff. Of all of the comments that were shared with me in the interviews conducted in 1994, I was most interested in those that had to do with the ways in which Iroquois staff were affected by visitor comments and the working conditions of being at a museum. Romariticized attitudes about how Native people are have created a Pan-Indian mythology in the minds of many Euro-Americans. Expectations of visitors seriously impact upon the learning that can occur. Consistent expressions of erroneous beliefs, and irisensitivity on the part of visitors who literally ask to see "real" Indians, tipis, and feathers, has proven to be too overwhelming for the Iroquois who work on staff at the museum. A 
high turn-over of Iroquois staff is a problem. In part because of loneliness for family and community (the museum is not located near any of the Iroquois communities), iroquois staff often leave to return home because they feel like they are on exhibit. But Iroquois presence is valued and considered a needed aspect of museum education at the IIM. A possible solution for this, according to Rick Hill, is in hiring Indians as guest curators or consultants. Hiring native persons affirms lived culture as a worthwhile form of knowledge and expertise.

4. The Museum Audience. Visitors to the IIM seem to expect an encounter with "a real Indian" and appear to be disappointed when such does not occur. Comments from participants suggest that visitors bring with them to the IIM a wide array of misinformation concerning Native people and their histories. Staff are challenged in how to manage the fascination that visitors have for Indian cultures and at the same time challenge visitors' thinking regarding Indian people. Helping visitors to break old attitudes, stereotypes and assumptions means challenging many romanticized notions which many non-Natives hold about Native American people. Other challenges to this museum include having to be selective with information shared with certain visitors. For example, not everyone seems to be able to understand the concept that for certain Iroquois artists the materials with which they work, such as clay and stone, are considered to be literally alive.

5. Educational Tools/Resources of the Museum. The liM utilizes informational and learning resources in ways similar to other museums. However, the utilization of aspects of contemporary Iroquois culture to provide understanding of contemporary Iroquois art is of special interest. Likewise, the exhibition of contemporary Iroquois art is the main access utilized by the museum to help visitors begin to understand the realities of contemporary Iroquois life. The art within the museum is not considered solely out of context. The museums presents other events and activities so that visitors can more easily understand the content of much of the Iroquois art it presents. Opportunities to interact with Iroquois staff and artists allow visitors to ask their questions and receive information directly from the Iroquois individuals at hand. This also raises the point about authenticity and the experience that visitors have when they have the opportunity to speak with Native individuals. Several of the non-Native staff commented on the difference with which visitors respond to staff depending upon whether they are Iroquois or non-Native. My impression was that this was especially true for children who visit the museum, i.e., that it is an exciting experience to meet "an Indian." The challenge then is how to maintain an atmosphere of respect towards the Native persons who work at the museum while at the same time try to direct non-Native curiosity and comments. 
6. Iroquois (Native) Voice and Participation. As a museum, the liM could not be easily duplicated elsewhere. A major part of the success of the museum lies in its years-long history of communication between the museum founders and several Iroquois individuals. The ability of Dr. Johannsen Hanks to create a relationship that included the skill of listening is key to the existence of the IIM. Through board participation, staff, and interns the IIM is aware of and responsive to the opinions of many Iroquois communities. Iroquois visitors to the museum are asked for their opinions and the staff responds in a variety of ways. For example, rewriting label text or even adding an additional label, if necessary, to express another iroquois viewpoint regarding an idea or object on display would not be an unusual response. This is not to imply that all Iroquois agree with all that the IIM says or does. But the ability of the museum staff to listen to an communicate with Iroquois persons is vital to its attempts at presenting Iroquois culture. The museum is also challenged in how to remain neutral. Because it does not focus on a single nation among the Iroquois and rather tries to emphasize all of the Iroquois, the museum is able to stay clear, for the most part, from factions and political controversy which may be circulating among the Iroquois communities, and the museum is sensitive to issues about the ways in which religious matters are discussed and presented.

7. Complexities of Accessing Iroquois (Native) art. To begin a presentation within any museum on even one Native culture is a tremendous task. The richness, depth and intricate complexities of presenting the Iroquois culture alone is a major effort. No one museum can say everything about a culture. Indeed, as John Fadden told me, a museum can reflect culture but it cannot contain it. Therefore, the IIM presents a reflection of contemporary Iroquois culture and lives through the contemporary art that it displays. But a single visit to the IIM cannot fully answer all questions or erase all stereotypes. The commitment that the staff expects from a core of volunteers cannot be assumed lightly. The knowledge to be developed is broad and an investment of time and effort towards educating staff, volunteers, and visitors is not insignificant. There is much to learn about the reality of Native lives and the commitment to learning accurate information is a commitment of time.

8. The Main Educational Goal of the Museum. Across the board, according to all participants, the perceived goal of the IIM is in the attempt to erase stereotypical attitudes about Native American people. For Dave Fadden there is the need for people to know that the Iroquois are still here. The IIM hopes that it can provide visitors with knowledge and understanding of Iroquois lives and it uses contemporary lroquois art to begin that process. 
Stereotypes and misinformation come from many sources. As Rick Hill told me, Native people who seek to provide accurate information about indian realities are fighting "Toys-R-Us and Hollywood." But museums may be an eventual positive resource for changing the false impressions that many people have regarding Native lives. This problem of stereotypes seems to pervade over everything at the museum. indeed, the mission of the museum is to inform visitors that Indians, specifically in this case Iroquois, are not located in the past.

In this paper I have tried to suggest the content of the interviews that I was able to conduct during my study at The Iroquois indian Museum. Space does not allow me to fully express the content of the interesting and insightful comments made by the individuals who gave generously of their time in answering my questions. I think that the interviews conducted for this study are of great worth and interest as educators and museum personnel attempt to teach ourselves, students, and our museum audiences about Native culture.

For me, this experience has suggested several questions regarding art education in general. What Pan-Indian beliefs do we perpetuate in classrooms and in galleries? In addition to our skills in studio production, criticism, and art history, have we also developed skilts in listening and questioning with respect? Are we who are non-Natives willing to suspend our own attitudes and beliefs about Indians to learn the realities of their lives and the context from which their art is regarded? Are we as educators willing to acknowledge our practices of art education which have been insensitive, especially in regards to the creation of objects which relate to Native religions, and take the time to accurately re-educate ourselves towards the purpose of presenting accurate information to our students and museum visitors?

This is a moment in history in which museums are being confronted by those usually excluded. Like other marginalized groups, Native Americans are also asking that their voice be heard in affirming who they are. Museums can be a strong starting point for the eradication of stereotypes if patience and sensitivity are utilized. Through this experience what I have learned, and want to share, is a sense that while many Native persons seek to have us listen, they are also willing to invite us into a dialog. Perhaps we are only in the beginning stages of a new paradigm, which no doubt will be constantly reworked, but it derives from such a beginning that the possibility exists for creating an understanding between people. 